Creative commons User License: CC BY-NC-ND

Abstracted by: EBSCOhost, Electronic Journals Service (EJS),

Google Scholar, Directory of Open Access Journals (DOAJ),

Journal Seek, Scientific Commons,

Food and Agricultural Organization (FAO), CABI and Scopus
Journal of Agricultural Extension

Vol. 21 (2) June, 2017

ISSN(e): 24086851; ISSN(Print); 1119944X

http://journal.aesonnigeria.org

http://www.ajol.info/index.php/jae

Email: editorinchief@aesonnigeria.org

\title{
Perception of Mealybug Wilt Effect and Management among Pineapple Farmers in Ghana \\ https://dx.doi.org/10.4314/jae.v21i2.1
}

\author{
Sarpong, Tutu Mark \\ Department of Crop Science \\ College of Agriculture and Natural Sciences (CANS) \\ University of Cape Coast \\ Cape Coast \\ martusary@yahoo.co.uk. Phone: +233244953044
}

\author{
Asare-Bediako, Elvis \\ Department of Crop Science \\ College of Agriculture and Natural Sciences (CANS) \\ University of Cape Coast \\ Cape Coast \\ easare-bediako@ucc.edu.gh, Phone:+233206124157
}

\author{
Acheampong, Lawrence \\ Department of Agricultural \\ Economics and Extension \\ College of Agriculture and Natural Sciences (CANS) \\ University of Cape Coast \\ Cape Coast \\ lacheampong@ucc.edu.gh; Phone:+233509640497
}

\begin{abstract}
Mealybug wilt of pineapple (MWP) is a major viral disease of pineapple [Ananas comosus (L) Merr.] in Ghana. Its incidence and extent of damage have not been extensively studied in the country. The study was conducted to determine pineapple farmers' perception of the effect and management of the MWP disease in Ghana. Structured interview schedule and questionnaire were used to solicit information from 227 pineapple farmers in the Central and Eastern regions of Ghana. Data were analysed using descriptive statistics including percentage, mean and standard deviation. Majority (73.1\%) of the respondents were aged between 31 and 50 years and were mainly senior secondary or senior high school leavers (52.2\%) and had been growing pineapples between 5 and 20years (82.6\%). All respondents indicated that they had experienced MWP in their pineapple farms and were able to give a vivid description of the disease symptoms. The farmers further indicated that the severity of MWP was high in smooth cayenne (100\%), sugar loaf (96.9\%) and Queen Victoria (91.2\%) but low in MD2 (100\%) varieties of pineapple. More than two-thirds of respondents indicated that they were losing between $1 \%$ and $20 \%$ of their yield per hectare and up to GHC 1000.00 (US\$248.00) per hectare to the disease. Majority of the respondents managed MWP by practicing land fallowing, avoiding infected mother plots for suckers, treating the soil, mother plots and suckers with insecticides to destroy mealybug vectors and their ant symbionts.
\end{abstract}

Keywords: Mealybug Wilt Effect, Mealybug Management, Mealybug in Pineapple, Mealybug in Ghana 
Creative commons User License: CC BY-NC-ND

Abstracted by: EBSCOhost, Electronic Journals Service (EJS), Google Scholar, Directory of Open Access Journals (DOAJ), Journal Seek, Scientific Commons,

Food and Agricultural Organization (FAO), CABI and Scopus
Journal of Agricultural Extension

Vol. 21 (2) June, 2017

ISSN(e): 24086851; ISSN(Print); 1119944X

http://journal.aesonnigeria.org

http://www.ajol.info/index.php/jae

Email: editorinchief@aesonnigeria.org

\section{Introduction}

Pineapple [Ananas comosus (L) Merr.] is the most economically important plant and the most developed horticultural crop in the Bromeliaceae family in Ghana (Bruce et al., 2000; d'Eeckenbrugge et al., 2003). It is cultivated predominantly for its fruit that is consumed fresh or as canned fruit and juice. The edible portion constitutes about $60 \%$ of the fruit. Pineapple fibre has also been processed into paper with remarkable qualities of thinness, smoothness and pliability (Collins, 1960; Rice et al., 1990; Montinola, 1991).

The contribution of pineapple to the economy of Ghana has been immense. Pineapple production creates employment and hence a source of income for thousands of people ranging from farmers to market women. The establishment of factories for the processing of pineapple at Bawjiase (Central Region), Asamankese, Nsawam, Adeiso (Eastern Region), Tema and Accra (Greater Accra Region), Ho and Tafe in the Volta Region, is a boost for cottage industrialization (Ministry of Food and Agriculture [MoFA], 2006; Central Regional Development Commision, 2006). Pineapple is an important non-traditional export crop in Ghana and hence a source of foreign exchange. In 2012 US $\$ 16,816,000$ was realized from the export of 41,212 metric tonnes (MoFA, 2013).

Unfortunately, the production of pineapple is being threatened by pests and diseases. Mealybug wilt of pineapple (MWP) is one of the most destructive diseases of pineapple in Ghana. It is a major constraint to the global production of pineapple (Rohrbach et al., 1988; Wakman et al., 1995). MWP is caused by Pineapple mealybug wilt associated virus (PMWaV; genus Ampelovirus, family Closteroviridae) transmitted by two species of mealybug, the pink pineapple mealybug, Dysmicoccus brevipes (Cockerell), and the gray pineapple mealybug, D. Neobrevipes Beardsley, (Carter, 1963; Sether et al., 1998; 2001; 2005). Effective management of the MWP is quite important in order to improve productivity and production of pineapple in the country, leading to more employment. This will enhance farmers' income and foreign exchange from pineapple export and consequently improving the economy of Ghana.

Information on farmers' awareness of MWP disease and their perception on the effect of the disease on the productivity of pineapple is an important pre-requisite for developing an effective strategy for managing the MWP disease in pineapple orchards. Such information is however very scanty in Ghana. It is against this background that this study was conducted to determine the perception of pineapple farmers in Ghana on the effect and management of MWP. Specifically, the study sought to:

1. describe the demographic characteristics of farmers in the study area;

2. ascertain farmers' knowledge level on mealybug wilt of pineapple;

3. find out farmers' perception on the incidence and severity of the mealybug wilt of pineapple; and

4. identify management practices farmers used in the controlling of mealybug wilt of pineapple 
Creative commons User License: CC BY-NC-ND

Abstracted by: EBSCOhost, Electronic Journals Service (EJS),

Google Scholar, Directory of Open Access Journals (DOAJ),

Journal Seek, Scientific Commons,

Food and Agricultural Organization (FAO), CABI and Scopus
Journal of Agricultural Extension

Vol. 21 (2) June, 2017

ISSN(e): 24086851; ISSN(Print); 1119944X

http://journal.aesonnigeria.org

http://www.ajol.info/index.php/iae

Email: editorinchief@aesonnigeria.org

\section{Methodology}

The study was conducted in the Eastern and Central Regions of Ghana and targeted respondents were registered pineapple growers in the two regions who are in farmerbased associations. The total number of the target respondents was 350 . This was made up 150 from the Eastern Region and 200 from the Central Region. According to Krejcie and Morgan (1970), the required sample size for the study should be 183. However, in order to reduce the sampling error 227 respondents were selected. In order to ensure a fair representation from the two regions, proportionate stratified sampling procedure was used to select 100 farmers from the Eastern region and 127 from the Central region. Structured interview schedule and questionnaires were used to collect data from the respondents. The questionnaire was used for the literate respondents whereas those who could not read and write responded to the structured interview scheduled. With the exception of sex and type of labour respondents used for fruit harvesting which were measured on a nominal scale all the other sociodemographic data were measured on an ordinal scale. Respondents were presented with series of statements to test their knowledge level where there were required to respond with either 'yes or no'. A 5 point Likert-type scale was used to measure the respondents' perception on the incidence and severity of the MWP. Means were calculated from a scale of $1=$ strongly disagree, $2=$ disagree, $3=$ somewhat disagree, $4=$ agree and $5=$ strongly agree. With management practices the respondents used to deal with the disease, they were asked to respond to series of statements by ticking. The researcher and two trained enumerators were involved in data collection which lasted for a period of one month. Data were analysed using percentage distribution, mean and standard deviation with Statistical Product and Service Solutions (SPSS) programme, version 21.

\section{Results and Discussion}

\section{Farm and Farmer Related Characteristics of the Respondents}

Table 1 provides information on farm and farmer characteristics. The majority of the respondents (91.5\%) were between 20 and 50years of age whilst only $8.5 \%$ were above 50 years. This result is consistent with the finding by Asare-Bediako et al. (2015) which states that most pepper farmers in Ghana are in the age range of 3059 years. This suggests that most of the respondent farmers were within the productive age (Apantaku et al., 2016). Thus pineapple production in these two regions is dominated by youth. All the respondents (100\%) were males. The dominance of males in pineapple production is expected because pineapple production is labour intensive which may be too tedious for most women, as reported by Apatanku et al. (2016) Again, the customary land ownership types existing in most areas of Ghana are more favourable to males than females, and this is corroborated by Duncan (2004), who reported that access to and control of land is

influenced by customary law and the limited role of women in original acquisition and leadership in traditional authority. 
Creative commons User License: CC BY-NC-ND

Abstracted by: EBSCOhost, Electronic Journals Service (EJS), Google Scholar, Directory of Open Access Journals (DOAJ), Journal Seek, Scientific Commons,

Food and Agricultural Organization (FAO), CABI and Scopus
Journal of Agricultural Extension

Vol. 21 (2) June, 2017

ISSN(e): 24086851; ISSN(Print); 1119944X

http://journal.aesonnigeria.org

http://www.ajol.info/index.php/jae

Email: editorinchief@aesonnigeria.org

The majority of the respondents $(52.2 \%)$ were senior secondary school/senior high school leavers whilst $2.5 \%$ of respondents had technical or vocational education as their highest educational qualification. It was noted that $20.9 \%$ and $8.0 \%$ of the farmers had bachelors' and masters' degree, respectively. The results show that unlike other agricultural industries in Ghana which are dominated by illiterate farmers, the pineapple business is mainly a vocation for the literate farmers. The results on the farmers' experience in pineapple cultivation as shown in Table 1 indicates that the majority of them (78.7\%) had been cultivating pineapples between five and twenty years. A further $15 \%$ of them had been in pineapple cultivation for over 20 years whilst only $2.5 \%$ of them had less than 5 years' experience. This finding indicates that most of the respondents have a vast experience in the pineapple business. The high level of education and vast experience in farming among respondents are likely to aid adoption of improved agronomic practices aimed at managing MWP and improving yields of pineapple as reported by AfariSefa et al. (2015). Nagaraju et al. (2002) have reported that formal education as well as and experience in farming can serve as a means through which farmers get informed. Apantaku et al. (2016) also argued that farmers' experience in farming count more than formal education in order to increase productivity.

The results of the study indicate that the majority of the respondents $(51.6 \%)$ were large scale farmers cultivating pineapple on land sizes of over 20 hectares, with $47.4 \%$ cultivating land of less than 20 hectares. This finding is contrary to the report of MoFA, (2011) which states that agriculture in Ghana is predominantly on a smallholder basis. However, MOFA, (2013) had reported that agriculture in Ghana is predominantly smallholder based with farmers farming on lands less than five hectares although there are other large farmers in other crops including pineapple. The common type of land ownership predominant amongst the respondents $(82.1 \%)$ was leasehold whilst others acquired their lands either through inheritance $((8 \%)$, or through outright purchase $(9.9 \%)$. This result is so because most of the respondents do not hail from these pineapple growing communities, hence the easiest way to have access to land is through lease.

More than two thirds $(68.7 \%)$ of respondents indicated that they were getting their planting materials from their own and neighbours' farms. It has however been reported that buying planting materials from other farms is a common source of infection and spread of the MWP (Sether et al., 1998). 
Creative commons User License: CC BY-NC-ND

Abstracted by: EBSCOhost, Electronic Journals Service (EJS), Google Scholar, Directory of Open Access Journals (DOAJ), Journal Seek, Scientific Commons,

Food and Agricultural Organization (FAO), CABI and Scopus

\section{Table 1: Farmer and farm characteristics}

Farmer Characteristics

\section{Age}

20-30 years

$31-40$ years

41-50 years

Above 50 years

Gender

Male

Female

Educational level

JHS/JSS

Middle school

SSS/SHS

Bachelor

Masters

Technical/Vocational

Number of years in pineapple cultivation

Below 5 years

$5-10$ years

$10-15$ years

$15-20$ years

Above 20 years

Total farm size under pineapple cultivation

$<20$ ha

20-40 ha

40-60 ha

$>60$ ha

Type of labour for fruits harvesting

Permanent

Journal of Agricultural Extension

Vol. 21 (2) June, 2017

ISSN(e): 24086851; ISSN(Print); 1119944X

http://journal.aesonnigeria.org

http://www.ajol.info/index.php/jae

Email: editorinchief@aesonnigeria.org

Percentage $(n=227)$

18.4

38.3

34.8

8.5

100

0

11.4

5.0

52.2

20.9

8.0

2.5

2.5

26.9

28.9

26.9

15.0

47.4

5.6

3.1

43.9

Casual/contract

Type of land ownership

Leasehold

82.1

Inherited

8.0

Outright purchase

9.9

Source of planting materials

Own farm

$28 . .2$

Other farms

Own and other sources

69.6

Source of information

Agricultural Extension Agents

Agro input dealers

45.8

Mass media (television, newspaper, radio)

53.9

Family and friends

45.8

Other farmers

69.2

Others

64.1

Source: Field Survey, 2014 
Creative commons User License: CC BY-NC-ND

Abstracted by: EBSCOhost, Electronic Journals Service (EJS),

Google Scholar, Directory of Open Access Journals (DOAJ),

Journal Seek, Scientific Commons,

Food and Agricultural Organization (FAO), CABI and Scopus

\author{
Journal of Agricultural Extension \\ Vol. 21 (2) June, 2017 \\ ISSN(e): 24086851; ISSN(Print); 1119944X \\ http://journal.aesonnigeria.org \\ http://www.ajol.info/index.php/jae \\ Email: editorinchief@aesonnigeria.org
}

Pesticide Initiative Programme [PIP] (2004) has also argued that with careful selection of healthy genetically whole planting materials diseases could in the long run be eliminated from the any variety of pineapple. This is suggestive that encouraging the farmers to as much as possible depend upon their own source for planting materials and teaching them the characteristic symptoms of MWP could go a long way in managing the disease situation by rogueing out all diseased plants from their fields. The majority of the farmers $(68.7 \%)$ employed permanent workers as a main source of labour whilst the others (57.8\%) use casual/contract workers for their farm activities. Table also indicates that $88.1 \%$ of the farmers have never had contact with agricultural extension agents (AEAs) and had not received any type of agricultural services. This situation can affect the adoption of good crop husbandry practices and new technologies by the farmers, since farmers may depend solely on other sources such as electronic media and neighbours for information.

\section{Farmers' Knowledge of Mealybug Wilt of Pineapple}

Table 2 provides information on the knowledge level of farmers on the Mealybug Wilt of pineapple (MWP) disease. Pineapple farmers were very familiar with the symptoms of the MWP and other wilting conditions. This result is not surprising since all the respondents had some level of education and also had vast experience in pineapple cultivation (see Table 1). As could be observed from Table 2 all $(100 \%)$ the respondents indicated that they had knowledge of the MWP disease. The result also indicates thatbetween $97 \%$ and $100 \%$ of the respondents were able to differentiate between the MWP and water stress or agrochemical wilt in pineapple and indicated that definite and sudden change in leaf colour, drying up of affected leaves, leaf tip die back, new central leaf growth and presence of mealybug underneath were characteristics of MWP as described by Broadley et al. (1993) and PIP (2004). With respect to the wilting conditions due to water stress or agrochemicals, respondents (100\%) indicated that the affected plants were evenly distributed in the field, appeared few days after fertilizer/agro chemical application and were isolated and spotted. 
Creative commons User License: CC BY-NC-ND

Abstracted by: EBSCOhost, Electronic Journals Service (EJS),

Google Scholar, Directory of Open Access Journals (DOAJ),

Journal Seek, Scientific Commons,

Food and Agricultural Organization (FAO), CABI and Scopus
Journal of Agricultural Extension

Vol. 21 (2) June, 2017

ISSN(e): 24086851; ISSN(Print); 1119944X

http://journal.aesonnigeria.org

http://www.ajol.info/index.php/jae

Email: editorinchief@aesonnigeria.org

Table 2: Farmers' knowledge on mealybug wilt of pineapple

Variable Percentage $(n=227)$

Do you have any knowledge of the mealybug wilt disease?

Yes

Symptoms of MWP

Light reddening of leaves

100

Definite and sudden change in leaf

100

colour

The leaf tip die back

96.9

Affected leaves dry up

100

New central leaf growth

100

Presence of mealybug underneath

100

How other wilting condition other

mealybug wilt present

Yellowing of leaves

Tip bur

Evenly distributed amongst the plants

100

Appear few days after agro inputs

100

application

Isolated and spotted

100

Source: Field Survey data, 2014. 
Creative commons User License: CC BY-NC-ND

Abstracted by: EBSCOhost, Electronic Journals Service (EJS),

Google Scholar, Directory of Open Access Journals (DOAJ),

Journal Seek, Scientific Commons,

Food and Agricultural Organization (FAO), CABI and Scopus
Journal of Agricultural Extension

Vol. 21 (2) June, 2017

ISSN(e): 24086851; ISSN(Print); 1119944X

http://journal.aesonnigeria.org

http://www.ajol.info/index.php/jae

Email: editorinchief@aesonnigeria.org

\section{Farmers' Perception of the Mealybug Wilt of Pineapple}

Information on farmers' perceptions of the MWP is shown in Table 3.The respondents strongly agreed that the MWP disease reduces yield of pineapple (mean $=5.00, \mathrm{sd}=0.00)$.

\section{Table 3: Distribution of respondents according to their perceptions of the mealybugwilt of pineapple}

\begin{tabular}{|c|c|c|}
\hline Statement & Mean & $\begin{array}{l}\text { Standard. } \\
\text { Deviation }\end{array}$ \\
\hline $\begin{array}{l}\text { The pineapple mealybug wilt disease reduce the yield of the } \\
\text { pineapple fruits }\end{array}$ & 5.00 & 0.00 \\
\hline $\begin{array}{l}\text { The mealybug wilt virus is more serious on field that no plastic } \\
\text { mulch is used }\end{array}$ & 4.99 & 0.21 \\
\hline The mealybug wilt virus is serious when the field is bushy & 4.98 & 0.16 \\
\hline $\begin{array}{l}\text { The mealybug associated virus disease is very serious during } \\
\text { the rainy season }\end{array}$ & 4.62 & 0.72 \\
\hline $\begin{array}{l}\text { The pineapple mealybug wilt disease can destroy the entire } \\
\text { farm if not treated }\end{array}$ & 4.05 & 1.03 \\
\hline Ants are the carriers of the mealybugs from place to place & 4.36 & 1.03 \\
\hline $\begin{array}{l}\text { The greater the mealybug population of the pineapple farm the } \\
\text { greater the incidence and severity of the pineapple mealybug } \\
\text { wilt disease }\end{array}$ & 4.11 & 0.91 \\
\hline Incidence of MWP is high in fields with high plant density & 3.95 & 1.47 \\
\hline $\begin{array}{l}\text { Plant affected by the pineapple mealybug wilt disease need to } \\
\text { be destroyed together with all plants within } 1 \mathrm{~m} \text { radius around } \\
\text { it }\end{array}$ & 3.39 & 1.31 \\
\hline $\begin{array}{l}\text { The mealybug associated virus disease is very serious during } \\
\text { the dry season }\end{array}$ & 3.17 & 1.33 \\
\hline $\begin{array}{l}\text { Controlling the ants and mealybug populations is a way of } \\
\text { checking the spread of the viruses }\end{array}$ & 3.28 & 1.20 \\
\hline $\begin{array}{l}\text { The mealybug wilt virus is more serious on field that plastic } \\
\text { mulch is used }\end{array}$ & 1.56 & 0.75 \\
\hline
\end{tabular}

Source: Survey data, 2014

They also strongly agreed that the disease was severe in the field with no plastic mulch (mean=4.99, $s d=0.21$ ), in bushy fields (mean=4.98, $s d=0.16$ ) and during the rainy season $(4.62, \mathrm{sd}=0.72)$. The respondents also agreed that ants are the carriers of the mealybugs from place to place (mean=4.36, $\mathrm{sd}=1.03$ ), the greater the mealybug population in the pineapple fields the greater the incidence and severity of the MWP disease (mean=4.11, $\mathrm{sd}=0.91$ ) and the MWP disease can destroy the entire fields if not treated' (mean=3.95, sd=1.47). Respondents however somewhat agreed that plants affected by pineapple mealybug need to be destroyed together with all plants within $1 \mathrm{~m}$ radius around it (mean=3.39, sd=1.31). Again the respondents somewhat agree that the disease is very serious during the dry season and controlling the ants and mealybug populations is a way of checking the spread of the virus disease. On 
Creative commons User License: CC BY-NC-ND

Abstracted by: EBSCOhost, Electronic Journals Service (EJS),

Google Scholar, Directory of Open Access Journals (DOAJ),

Journal Seek, Scientific Commons,

Food and Agricultural Organization (FAO), CABI and Scopus
Journal of Agricultural Extension

Vol. 21 (2) June, 2017

ISSN(e): 24086851; ISSN(Print); 1119944X

http://journal.aesonnigeria.org

http://www.ajol.info/index.php/jae

Email: editorinchief@aesonnigeria.org

the other hand, the respondents strongly disagreed to the statement that the MWP is more serious on fields that plastic mulch is used (mean1.56, sd=0.75). The respondents' level of agreement to the statements further indicates that they have vast experience in the pineapple business and their knowledge level in the MWP is very high. However, they lack in-depth knowledge of some factors which affect epidemiology of MWP in pineapple fields. For instance, it is known that controlling the ants and mealybug populations is a way of checking the spread of the viruses, as reported by Jahn et al. (2003) and this could be due to the poor extension services received by the farmers.

\section{Farmers' Perceptions of the Effect of Mealybug Wilt of Pineapple on Different Varieties of Pineapple}

Table 4 highlights the respondents' perception on the effect of MWP on different varieties of pineapple. All the respondents (100\%) indicated that the effect of the MWP was low on in MD2 variety and high in smooth cayenne. Also between $91.2 \%$ and $96.9 \%$ of the respondents indicated that the effect of the disease was high in the sugar loaf and Queen Victoria. This suggests that MD2 is more resistant whereas the other varieties (Queen Victoria, Smooth cayenne and sugar loaf) are more susceptible to MWP. This finding is in line with the reports of d'Eeckenbrugge and Leal (2003) and Jahn et al. (2003) which state that Smooth Cayenne and Queen Victoria varieties are susceptible to the MWP but resistant to the Phythophtora rot disease whereas the MD2 is resistant to MWP but rather susceptible to the Phythophtora rot disease.

Table 4: Farmers' perceptions about the effect of mealybug wilt of pineapple on different varieties

Variety

$$
\text { Frequency (Percentage) }
$$

\begin{tabular}{lccc}
\cline { 2 - 4 } & High & Medium & Low \\
\hline MD2 & - & - & $110(100)$ \\
Smooth Cayenne & $159(100)$ & - & - \\
Sugar loaf & $154(96.9)$ & - & $5(3.1)$ \\
Queen Victoria & $62(91.2)$ & $6(8.8)$ & -
\end{tabular}

Source: Survey data, 2014.

\section{Farmers' Perceptions on Incidence and Severity of Mealybug Wilt of Pineapple at Pre- and Post-Induction Growth Stages of Four Varieties of Pineapple}

The majority of the respondents indicated that incidence and severity of the MWP was higher during the pre-flowering growth stage than the post-flowering growth stage in all the four pineapple varieties (Table 5). This result however, contradicts the report of PIP (2011) which states that MWP could be severe at all the growth stages of pineapples. 
Creative commons User License: CC BY-NC-ND

Abstracted by: EBSCOhost, Electronic Journals Service (EJS),

Google Scholar, Directory of Open Access Journals (DOAJ),

Journal Seek, Scientific Commons,

Food and Agricultural Organization (FAO), CABI and Scopus
Journal of Agricultural Extension

Vol. 21 (2) June, 2017

ISSN(e): 24086851; ISSN(Print); $1119944 X$

http://journal.aesonnigeria.org

http://www.ajol.info/index.php/jae

Email: editorinchief@aesonnigeria.org

Table 5: Distribution of the respondents' perceptions on incidence and severity of MWP at pre- and post-flower induction stage of the various pineapple varieties

\begin{tabular}{lcc} 
Varieties & \multicolumn{2}{c}{ Percentage } \\
\cline { 2 - 3 } & $\begin{array}{c}\text { Pre-flower } \\
\text { induction }\end{array}$ & $\begin{array}{c}\text { Post-flower } \\
\text { induction }\end{array}$ \\
\hline Growth Stage at which the incidence of MWP & \\
is high & 69.4 & 30.6 \\
MD2 & 66.5 & 33.5 \\
Smooth Cayenne & 81.0 & 19.0 \\
Sugar loaf & 76.2 & 23.8 \\
Queen Victoria & & \\
Growth stage at which MWP is severe & 76.7 & 23.3 \\
MD2 & 93.3 & 6.7 \\
Smooth Cayenne & 89.1 & 10.9 \\
Sugar loaf & 52.4 & 47.6 \\
Queen Victoria &
\end{tabular}

Source: Survey data, 2014

\section{Farmers' Perception on the Effect of Mealybug Wilt of Pineapple on Fruit Yield}

Table 6 shows the farmers' perception on the effect of MWP on fruit yield. Growers of the MD2 variety indicated that they were losing below $1 \%$ of their yield to the disease. The majority (45.3\%) of the growers of the smooth cayenne were losing between $41-60 \%$ of their yield, followed by $37.8 \%$ who were losing $21-40 \%$ of their fruit yield, with $16.9 \%$ losing $1-20 \%$ of their fruits. The majority $(46.3 \%)$ of respondents who grew the sugar loaf variety said they were losing between $1-20 \%$ of their yields, followed by $37.6 \%$ who were losing $41-60 \%$ of their fruits, with $16.1 \%$ losing 21-405 of their fruits.

Table 6: Farmers' perception on the effect of MWP on fruit yield

\begin{tabular}{lcccc}
\hline Yield loss (\%) & $\begin{array}{c}\text { MD2 } \\
(n=116)\end{array}$ & $\begin{array}{c}\text { Smooth } \\
\text { Cayenne } \\
(n=148)\end{array}$ & $\begin{array}{c}\text { Sugar Loaf } \\
(n=149)\end{array}$ & $\begin{array}{c}\text { Queen } \\
\text { Victoria } \\
(n=63)\end{array}$ \\
\hline Below 1 & 100 & - & - & - \\
$1-20$ & - & 16.9 & 46.3 & 11.1 \\
$21-40$ & - & 37.8 & 16.1 & 88.9 \\
$41-60$ & - & 45.3 & 37.6 & - \\
\hline
\end{tabular}

Source: Survey data, 2014.

The majority (88.9\%) of the growers of the Queen Victoria said they were losing between $21-40 \%$ of their yield whilst $11.1 \%$ were losing $1-20 \%$ of their fruits. These findings support the reports of Dey et al (2015) which state that MWP is a major constraint on the global production of pineapple. These results also confirm MD2 as 
Creative commons User License: CC BY-NC-ND

Abstracted by: EBSCOhost, Electronic Journals Service (EJS), Google Scholar, Directory of Open Access Journals (DOAJ), Journal Seek, Scientific Commons,

Food and Agricultural Organization (FAO), CABI and Scopus
Journal of Agricultural Extension

Vol. 21 (2) June, 2017

ISSN(e): 24086851; ISSN(Print); 1119944X

http://journal.aesonnigeria.org

http://www.ajol.info/index.php/jae

Email: editorinchief@aesonnigeria.org

resistant pineapple variety to MWP and Smooth Cayenne as the most susceptible variety as reported by PIP (2011).

\section{Effect of MWP on farmers' income}

Table 7 highlights on the effects of the MWP on the farmers' income. In respect of the respondents who sell their produce locally, 33.9\% said they were losing between 1001-2000 Ghana cedis (US\$ 244-488); 27.8\% said the disease causes losses in income ranging between 2001 and 3000 Ghana cedis (US\$ 488-732) whilst 26.9\% said they loss between 1 and 1000 Ghana cedis (US\$ $0.244-243$ ) in revenue due to MWP. For respondents who export their produce, $31.3 \%$ of them said they were losing between 1-1000 Ghana cedis (US\$ $0.244-243$ ), followed by $27.3 \%$ who said they were losing above 3000 Ghana cedis (above us $\$ 732$ ), and $16.3 \%$ who were losing between 1001 and 2000 Ghana cedis (US\$244-488), whilst 7\% said they were losing between 2001 and 3000 Ghana cedis (US\$ 488-732) in revenue due to the MWP disease. This results shows that the MWP disease has huge negative effect on the income on farmer income (Dey et al., 2015).

Table 7: Effect of mealybug wilt of pineapple on farmers' income

\begin{tabular}{lcc} 
& \multicolumn{2}{c}{ Percentage Loss } \\
Loss $(\mathrm{GH}))$ & Export $(\mathrm{n}=186)$ & Local sales $(\mathrm{n}=201)$ \\
\hline $1-1000$ & 31.3 & 26.9 \\
$1001-2000$ & 16.3 & 33.9 \\
$2001-3000$ & 7 & 27.8 \\
Above 3000 & 27.3 & - \\
\hline
\end{tabular}

Source: Survey data, 2014

\section{Farmers' Management Practices}

Table 8 shows the disease and pest management practices adopted by the respondents. The majority $(88.5 \%)$ of the respondents kept fallow plots whereas the remaining $11.5 \%$ did not. Out of those who kept fallow plots, $2.5 \%, 44.8 \%, 35.3 \%$ and $17.4 \%$ did it for 6 months, 12 months, 18 months and 24 months respectively. The practice of keeping fallow plots by the farmers could contribute to the management of MWP. PIP (2004) had observed that fallowing ensures that planted lands regain their fertility and helped to break disease and pest cycles.

The majority $(75.9 \%)$ of the respondent flag plots with diseased plants, whilst $8 \%$ tags diseased plants and this prevents the farmers from harvesting suckers from infected mother plots. Greater percentage of the respondents (87.2\%) said they prevent MWP in their farms by not harvesting suckers from infected fields (mother plots). The majority (88.55\%) of the respondents also control ants and mealybugs vectors from the mother plots with insecticides, mainly at 3 months (46.7\%) and 6 months (41.9\%) intervals. According to Mamoon et al. (2014) and Jallow et al. (2017) the use of insecticide to control ants and mealybugs is very effective. Some farmers $(8 \%)$ also physically destroy infected mother plots. These practices are indicative of the preventive measures that farmers take against MWP development in their farms. 
Creative commons User License: CC BY-NC-ND

Abstracted by: EBSCOhost, Electronic Journals Service (EJS),

Google Scholar, Directory of Open Access Journals (DOAJ),

Journal Seek, Scientific Commons,

Food and Agricultural Organization (FAO), CABI and Scopus
Journal of Agricultural Extension

Vol. 21 (2) June, 2017

ISSN(e): 24086851; ISSN(Print); 1119944X

http://journal.aesonnigeria.org

http://www.ajol.info/index.php/iae

Email: editorinchief@aesonnigeria.org

Table 8: Farmers' management practices

Variable Percentage $(\mathrm{n}=227)$

Keeping of fallow plots

Yes

Duration of Fallow

6 months

12 months

18 months

24 months

Keeping track of the diseased areas of planted field

Flagging plots with diseased plants

Tagging individual diseased plants

Indicating on the map of the plot

Control of mother plots against MWP

3 months interval

6 months interval

No treatment

Means by which mealybug wilt disease is prevented on mother plots

Insecticide spraying to destroy ants and mealy bugs

Physical destruction of infected mother plants

Not planting at the same spot for at least two seasons

Sucker harvesting from mother plots

Not harvesting suckers from an infected mother plant

Not harvesting from within $1 \mathrm{~m}^{2}$ perimeter of an infected

mother plant

Harvesting from all mother plants provided the suckers look

healthy

\section{Soil treatment before new planting}

Yes

Means by which soil is treated

Spraying with insecticides

Ploughing to expose soil to sun soil/burning

No action

Treatment used when replanting on an infected field

Spot treatment

67.6

Whole plot treatment

Means of treating suckers to prevent MWP

Dipping of suckers in fungicide/insecticide solution

Aim of application of insecticide

As preventive measure

As curative measure

Effectiveness of treatment against the mealybug wilt

Yes

Source: Survey data, 2014. 
Creative commons User License: CC BY-NC-ND

Abstracted by: EBSCOhost, Electronic Journals Service (EJS), Google Scholar, Directory of Open Access Journals (DOAJ), Journal Seek, Scientific Commons,

Food and Agricultural Organization (FAO), CABI and Scopus
Journal of Agricultural Extension

Vol. 21 (2) June, 2017

ISSN(e): 24086851; ISSN(Print); 1119944X

http://journal.aesonnigeria.org

http://www.ajol.info/index.php/jae

Email: editorinchief@aesonnigeria.org

These findings are thus in line with the recommendations of PIP (2004 and 2008) who reported that since mother plots are sources of planting materials, they should be kept weed-free, fertilized and protected from diseases and pests to ensure the production of healthy suckers. It has also been recommended that farmers should avoid using plants growing within a 1 metre radius as a source of planting material, if less than $3 \%$ of plants show wilt symptoms; and if more than $10 \%$ of plants in a field exhibit MWP symptoms farmers should not collect planting material (suckers) from it even if control of wilt appears effective (Jallow et al., 2017).

Whereas $53.7 \%$ did not treat their new plots against insects and MWP before planting, $46.3 \%$ treat their soil mainly with insecticides $(78.1 \%)$ and by ploughing to expose soil to sun/burning (14.3\%)before planting new suckers on plots that had previously been planted with pineapple. About $67.6 \%$ of those who treat their soil before replanting were doing spot treatment whereas $32.4 \%$ did whole plot treatment. As a preventive measure against MWP, the majority of farmers $(87.6 \%)$ drench suckers 3-7 days after planting in new plots, whereas others (12.4\%) dip suckers in fungicide/insecticide solution. Jahn et al. (2003) had indicated that to control the MWP it is important to first control the ants especially the Pheidole with insecticides. The majority $(94.6 \%)$ of respondents apply insecticide as a preventive measure as opposed to $5.4 \%$ who applied as curative measure. This results agrees with Jallow et al (2017), who assert that most farmers use pesticides to stop pests from attacking their crops. Most $(88.5 \%)$ farmers said the treatment against the ants and mealybugs is effective while $11.5 \%$ were indifferent. It has been recommended that when the incidence of MWP exceeds $3 \%$, a mealybug control programme is justifiable (Anonymous, 2005).

\section{Conclusion and Recommendations}

The results of the study indicate that all the respondents have adequate knowledge on mealybug wilt of pineapple. They were able to identify the major symptoms of MWP and could distinguish between MWP and other wilting conditions. According to the study the incidence and severity of MWP was high during flowering stage than post flowering stage. Again the study showed that MD2 is very resistant to MWP while smooth cayenne is the most susceptible variety to the disease. The findings showed that the respondents employ varying strategies to manage the disease. Some of the management strategies include keeping of fallow plots to break the disease cycle, treating mother plots and soil with insecticides especially plots with history of the MWP incidence, as well as avoiding infected mother plots for planting materials, flagging of affected plots and destruction of affected plants.

The Ministry of Food and Agriculture through agricultural extension agents should extend services to pineapple farmers on good agronomic practices involved in pineapple cultivation. The farmers should be educated on factors that affect the epidemiology of MWP in pineapple farms and effective disease management strategies. 
Creative commons User License: CC BY-NC-ND

Abstracted by: EBSCOhost, Electronic Journals Service (EJS), Google Scholar, Directory of Open Access Journals (DOAJ), Journal Seek, Scientific Commons,

Food and Agricultural Organization (FAO), CABI and Scopus
Journal of Agricultural Extension

Vol. 21 (2) June, 2017

ISSN(e): 24086851; ISSN(Print); 1119944X

http://journal.aesonnigeria.org

http://www.ajol.info/index.php/jae

Email: editorinchief@aesonnigeria.org

\section{Reference}

Anonymous. (2005). Pineapple Best Practices Manual.Mealybug wilt version 1, 1 pp 5-8.

Apantaku, S.O, Aromolaran, A.K., Shobowale, A.A. and Sijuwola, K.O. (2016). Farmers and extension personnel view of constraints to effective agricultural extension services delivery in Oyo State, Nigeria. Journal of Agricultural Extension 20(2), 202-214.

Afari-Sefa, V., Asare-Bediako, E., Kenyon, L. and Micah, J. A. (2015). Pesticide use practices and perceptions of vegetable farmers in the cocoa belts of the Ashanti and Western Regions of Ghana. Advances in Crop Science and Technology, 3 (174): 1-10.

Asare-Bediako, E., A. Addo-Quaye, A., B. Boakye, B. Sarbah J. M., Asante, P. and Dorm, E. (2015). Incidence and severity of viral and fungal diseases of chili pepper (Capsicum frutescens) in some districts in Ghana.International Journal of Plant and Soil Science, 7(3): 147-159, 2015.

Broadley, R.H., Wasserman, R.C. \& Sinclair, E.R. (1993) Pineapple Pests and Disorders.Department of Primary Industries. Brisbane, Australia, $63 \mathrm{pp}$.

Bruce, P. A M. and Oku, S. (2000). Survey on non-traditional crops in Ghana.Accra:Ministry of Agriculture, Policy Planning Monitoring and Evaluation Directorate.

Carter, W. (1963). Mealybug wilt of pineapple: A reappraisal. Annals of New York Academy of Science, 105,741-764.

Central Regional Development Commision (2006). Investment opportunities: fishing, pineapple and cashew, oil palm and cassava . 2. Cape Coast: CEDECOM

Collins, J. L., (1960). The Pineapple - Botany, cultivation and utilisation. New York: Interscience Publishers.

Krejcie, R.V. \& Morgan, D.W. (1970). Determining sample size for research activities. Educational and Psychological Measurement, 30, 607-610.

d'Eeckenbrugge, G.C and Leal, F. (2001). Pineapple accessed on 02/09/25 20:16 GMT from www.ciatweb.ciat.cgiar.org/ipgri/fruits.../more\%20about\%20pineapple.htm

d'Eeckenbrugge, G, C. and Leal, F. (2003). "Chapter 2: Morphology, Anatomy, and Taxonomy". In D.P Bartholomew, R.E. Paull, and K.G. Rohrbach. The Pineapple: Botany, Production, and Uses. Wallingford, UK: CABI Publishing. p. 21.

Dey, K.K., Borth, W.B., Melzer, M.J., Wang, M., \& Hu, J.S. (2015). Analysis of pineapple wilt associated virus-1 and -2 for potential RNA silencing suppressors and pathogenicity factors. Virus, 7(3), 969-995.

Duncan, B.A. (2004) Women in Agriculture in Ghana. Second edition. Accra: Fredrich Ebert Foundation, p 119.

Jahn, G.C., Beardsley, J. W. and González-Hernández, H. (2003). A Review of the association of ants with mealybugwilt disease of pineapple. Proceedigs. of the Hawaiian Entomological. Society, 36, 9-28.

Jallow, M.F.A., Awadh, D.G., Albaho, M.S., Devi, V.Y., \& Thomas, B.M. (2017). Pesticide knowledge and safety practices among farm workers in Kuwait: 
Creative commons User License: CC BY-NC-ND

Abstracted by: EBSCOhost, Electronic Journals Service (EJS),

Google Scholar, Directory of Open Access Journals (DOAJ),

Journal Seek, Scientific Commons,

Food and Agricultural Organization (FAO), CABI and Scopus
Journal of Agricultural Extension

Vol. 21 (2) June, 2017

ISSN(e): 24086851; ISSN(Print); 1119944X

http://journal.aesonnigeria.org

http://www.ajol.info/index.php/jae

Email: editorinchief@aesonnigeria.org

Results of a survey. International Journal of Environmental Research and Public Health, 14(340), 1-15

Mamoon, R., Bushra, S. \& Tarig, M. (2014). Use and impact of insecticides in mealybug control. International Journal of Advances in Biology, 1(2), , 1-11 Ministry of Food and Agriculture (2006). Agriculture in Ghana Facts and Figures. Accra, Ghana: Statistics, Research and Information Directorate (SRID) of Ministry of Food and Agriculture.pp 36.

Ministry of Food and Agriculture (2011). Agriculture in Ghana Facts and Figures. Accra, Ghana: Statistics, Research and Information Directorate (SRID) of Ministry of Food and AgricultureRetrieved from http://mofa.gov.gh/site/wpcontent/ uploads/2014/03/AGRICULTURE-IN-GHANA-FF-2012-nov-2013.pdf on $16^{\text {th }}$ May 2014.

Ministry of Food and Agriculture (2013). Agriculture in Ghana Facts and Figures. Accra: Ghana: Research and Information Directorate (SRID) of Ministry of Food and Agriculture. pp 65.

Montinola, L. R. (1991). Pina. Manila, Philippines: Amon Foundation.

Nagaraju, N., Venkatesh, H. M., Warburton, H., Muniyappa, V., Chancellor, T. C. B., and Colvin, J. (2002). Farmers' perceptions and practices for managing Tomato leaf curl virus disease in southern India, International Journal of Pest Management, 48, 333-338

Pesticide Initiative Programme (2004).MD2 Pineapple Variety Production Guide.COLEACP/PIP.

Pesticide Initiative Programme (2011). Guide to good crop protection practices for pineapple (Ananascomosus) in organic farming in ACP countries. COLEACP/PIP. P 40

Rice, R. P., Rice, L. W., \& Tindall, H. D. (1990). Fruits and Vegetables Production in Warm Climates. London: Macmillan Edu. Ltd 486p.

Rohrbach, K. G., Beardsley, J. W., German, T. L., Reimer, N. J.and Sanford, W. G. (1988). Mealybug wilt, mealybugs, and ants on pineapple. Plant Disease, 72 , 558-565.

Sether, D. M., Ullman, D. E., and Hu, J. S. (1998). Transmission of pineapple mealybug wilt-associated virus by two species of mealybug (Dysmicoccus spp.). Phytopathology, 88(11), 1224-1230.

Sether, D. M., Karasev, A. V., Okumura, C., Arakawa, C., Zee, F., Kislan, M. M., and $\mathrm{Hu}$, J. S. (2001). Differentiation, distribution, and elimination of two different pineapple mealybug wilt-associated viruses found in pineapple. Plant disease, 85(8), 856-864.

Sether, D. M. and Hu, J. S. (2002). Closterovirus infection and mealybug exposure are necessary for the development of mealybug wilt of pineapple disease. Phytopathology, 92(9), 928-935.

Sether, D. M., Melzer, M. J., Busto, J., Zee, F., and Hu, J. S. (2005). Diversity and mealybug transmissibility of ampeloviruses in pineapple. Plant Disease, 89(5), 450-456.

Wakman, W., Teakle, D., Thomas, J. E. and Dietzgen, R. G. (1995). Presence of a clostero-like virus and a bacilliform virus in pineapple plants in

Queensland.Australian Journal of Agricultural Research, 46, 847-958. 
Creative commons User License: CC BY-NC-ND

Abstracted by: EBSCOhost, Electronic Journals Service (EJS), Google Scholar, Directory of Open Access Journals (DOAJ), Journal Seek, Scientific Commons,

Food and Agricultural Organization (FAO), CABI and Scopus
Journal of Agricultural Extension

Vol. 21 (2) June, 2017

ISSN(e): 24086851; ISSN(Print); 1119944X

http://journal.aesonnigeria.org

http://www.ajol.info/index.php/jae

Email: editorinchief@aesonnigeria.org 